\title{
Mengenalpasti faktor imej kedai (KR1M) dalam mempengaruhi pengurusan kos sara hidup
}

\author{
Identify the factor of store image (KRIM) in affecting consumer management \\ in cost of living
}

Noor Fadzlin Abu Bakar'* \& Maisarah Ahmad ${ }^{2}$

${ }^{1}$ Universiti Kebangsaan Malaysia, Bangi, Selangor, Malaysia

${ }^{2}$ Universiti Teknologi Petronas, Seri Iskandar, Perak, Malaysia

*email: noorfadzlinabubakar@gmail.com

Received: 24 April 2020; Accepted: 12 June 2020; Published: 14 June 2020

To cite this article (APA): Abu Bakar, N. F., \& Ahmad, M. (2020). Mengenalpasti faktor imej kedai (KR1M) dalam mempengaruhi pengurusan kos sara hidup. EDUCATUM Journal of Social Sciences, 6(2), 1-9. https://doi.org/10.37134/ejoss.vol6.2.1.2020

To link to this article: https://doi.org/10.37134/ejoss.vol6.2.1.2020

\begin{abstract}
Abstrak
Kajian barangan berjenama persendirian yang telah dilakukan sebelum ini lebih tertumpu kepada pembelian pengguna terhadap barangan berjenama persendirian syarikat swasta. Oleh yang demikian, kajian ini memfokuskan kepada peranan Kedai Rakyat 1 Malaysia (KR1M) yang merupakan kedai barangan berjenama persendirian kerajaan. Objektif kajian ini ialah mengenal pasti dimensi imej kedai yang mempengaruhi pengurusan kos sara hidup. Berdasarkan kajian literatur, peranan KR1M telah diterjemahkan sebagai imej kedai yang merangkumi dimensi barangan, persekitaran, perkhidmatan, kebolehcapaian, reputasi, promosi, fasiliti dan perkhidmatan selepas pembelian. Manakala, keputusan pembelian di KR1M diangkat sebagai pengurusan kos sara hidup. Model psikologi persekitaran iaitu Stimulus-Organism-Response (S-O-R) (Mehrabian,1974) telah dijadikan teori asas kepada kerangka kajian ini. Stimulusnya ialah imej kedai, pembeli barangan KR1M ialah organisma dan pengurusan kos sara hidup adalah respons. Sejumlah 330 borang soal selidik yang lengkap diisi oleh pembeli jenama persendirian di KR1M telah berjaya dikumpulkan secara pensampelan mudah di kalangan pembeli barangan KR1M sekitar Lembah Klang. Setelah kajian dijalankan, pengkaji mendapati bahawa imej kedai ialah stimuli penting dalam mendapat perhatian pelanggan bagi membuat pembelian di kedai.
\end{abstract}

Kata Kunci: Barangan berjenama persendirian, imej kedai, pengurusan kos sara hidup, Kedai Rakyat 1 Malaysia

\begin{abstract}
The previous survey in private label brand is more focused on consumer purchases. Consequently, this study focuses on the role of Kedai Rakyat 1 Malaysia (KRIM), a government initiative, in influencing cost of living management amongst consumers. The purpose of this study is to identify store image dimensions affecting the cost of living. Based on literature review, the role of KR1M is operationalized as store image which includes the dimensions of product offerings, environment, service, accessibility, reputation, promotion, facilities and after sales services. Meanwhile, cost of living management is treated as purchase decision proxy. The environmental psychology model of the Stimulus-Organism-Response (S-O-R) (Mehrabian,1974) underpins the research framework of this study where stimulus is the store image, the KRIM buyers is the organism and the cost of living management is the response. A total of 330 completed questionnaires were successfully collected in a among KRIM patrons in the Klang Valley. Latest development, the existing KRIM has been upgraded to KRIM 2.0 where the opportunity of offering goods was offered to more than one retailer with the aim to improve the quality and diversity of goods offered. Hence, future research may explore retailer's effectiveness in ensuring the continuity of KRIM. After the study was conducted, the reviewer found that it turned out and was proven that the store's image was an important stimulus in getting the customer's attention to make purchases at the store.
\end{abstract}


Keywords: private label brand, store image, cost of living, Kedai Raykat 1 Malaysia.

\section{PENGENALAN}

Suasana sosiopolitik global yang kurang memberangsangkan kini, sedikit sebanyak mempengaruhi ramalan Bank Dunia yang menjangkakan pertumbuhan ekonomi dunia akan meningkat sedikit kepada 2.9 peratus berbanding 2.4 peratus pada tahun lalu, terutama dengan kejatuhan harga minyak global. Presiden Bank Dunia, Jim Yong Kim berkata, kajian Prospek Ekonomi Global oleh Bank Dunia yang diterbitkan pada Januari 2016, mendapati pertumbuhan global 2016 masih lemah, tetapi sedikit meningkat daripada 2.4 peratus pada 2015 kepada 2.9 peratus pada tahun ini dengan pemulihan ekonomi di negara-negara maju.

Malaysia sendiri telah membuat perubahan kepada Bajet 2016 setelah mengambil kira keadaan ekonomi global, kejatuhan nilai mata wang dan kejatuhan harga minyak serta harga komoditi yang memberi kesan langsung kepada pendapatan minyak negara dan pendapatan eksport. Laporan Bank Dunia itu juga menyatakan, kelembapan ekonomi yang dialami kebanyakan negara membangun akan merencatkan usaha membasmi kemiskinan dan membawa kemakmuran kepada penduduk selain daripada lebih 40 peratus penduduk miskin dunia berada di negara-negara membangun dan kebanyakan negara membangun ini mengalami pertumbuhan ekonomi yang lembap dan perlahan sepanjang 2015.

Keadaan ekonomi Malaysia menunjukkan kejatuhan yang agak banyak dalam pelaburan antarabangsa dan industri bagi tahun 2015 ini. Laporan daripada Unit Perancangan Ekonomi, Jabatan Perdana Menteri, import dagangan menunjukkan -0.4 bagi suku ke 3 tahun 2015, iaitu pengiraan sehingga bulan September. Terdapat beberapa kesan ekonomi dunia terhadap negara, antaranya kenaikan harga minyak, inflasi, kenaikan harga barangan. Pengeluar dan peruncit mencari jalan alternatif untuk mengatasi masalah yang disebabkan oleh kejatuhan ekonomi dan peningkatan kos sara hidup. Pengguna juga mencari barangan yang berkualiti tetapi agak murah. Kebanyakan peruncit terkemuka kini mempunyai jenama persendirian mereka sebagai contohnya Tesco dengan jenama Tesco Choice, AEON Sdn Bhd dengan jenama pakaian Jkids dan Giant dengan jenama barangannya sendiri iaitu First Choice. Kewujudan jenama-jenama persendirian daripada peruncit-peruncit terkemuka adalah untuk mengurangkan kos mengimport dan kos operasi (Mayer, 2009), ini sekali gus memberi peluang kepada pembeli untuk membeli dengan harga yang murah di pasar raya apabila mereka dengan membeli barangan jenama yang dikeluarkan sendiri oleh pasar raya tersebut.

Pada asalnya, peruncit mengeluarkan barangan berjenama persendirian ini bertujuan untuk keuntungan sendiri dan tidak memikirkan sehingga boleh menyaingi barangan berjenama yang lain (Kim \& Parker,1999). Hal ini demikian kerana pembuatannya melibatkan jenama yang tidak dikenali, pembungkusan yang tidak menarik dan kualiti yang rendah membuatkan barangan berjenama persendirian ini kurang dikenali (Young, 2005). Selari dengan keadaan dunia yang semakin membangun dan berkembang, sebahagian besar peruncit memperkenalkan barangan berjenama persendirian yang lebih berkualiti untuk bersaing dengan barangan berjenama nasional (Volpe \& USDA, 2011). Menurut Batra dan Sinha (2000), peningkatan permintaan terhadap barangan berjenama persendirian ini adalah disebabkan oleh peningkatan kemahiran peruncit dalam mengendalikan barangan berjenama persendirian di samping keinginan untuk mencapai sasaran keuntungan yang telah mereka tetapkan.

Kajian mengenai barangan berjenama persendirian ini lebih kepada mengkaji faktor-faktor yang mempengaruhi niat pengguna (Chaniotakis, Lymperopoulos, \& Soureli, 2010; Diallo, 2012; Tih \& Lee, 2013) dan mengenai faktor-faktor yang mempengaruhi pembelian pengguna (Ahmad, Mohd Noor, \& Che Wel, 2014; Akpoyomare, Patrick, \& Ganiyu, 2012; Wee, Fong, Kian, Fern, \& Vincent, 2015). Selain itu, pengkaji kini lebih tertumpu kepada barangan berjenama persendirian yang dijual secara talian di pasaran dunia (Eroglu, Machleit, \& Davis, 2003; Huang, 2012; Park, Kim, Funches, \& Foxx, 2012; Sherman, Mathur, \& Smith,1997). Walau bagaimanapun, kajian yang menjelaskan hubungan antara barangan berjenama persendirian dengan ekonomi adalah sangat terhad dan hanya melihat kepada perspektif pengeluar serta peruncit yang terkesan dengan keadaan ekonomi, tidak kepada pengguna (Ang, Leong \& Kotler, 2000). Kajian khusus mengenai pengaruh berjenama persendirian yang memfokuskan kepada Kedai Rakyat 1 Malaysia juga sangat terhad (Hafifi, 2016; Mohd Saifoul, Jalal, \& Amir Hussin, 2014). Kajian mengenainya hanya bertumpu kepada pengenalpastian faktor-faktor yang mempengaruhi pemilihan pengguna terhadap KR1M. Walau bagaimanapun, kajian mengenai KR1M 
membantu mengurangkan kos sara hidup dan membantu golongan berpendapatan rendah dan sederhana di kawasan bandar (B40) masih belum mendapat perhatian penyelidik.

Oleh itu, melalui kajian ini, pengkaji berhasrat untuk melihat sejauh mana pengaruh pembelian barangan berjenama persendirian iaitu KR1M dapat memberi kesan dalam membantu pengurusan kos sara hidup rakyat Malaysia yang berpendapatan rendah seperti yang disasarkan oleh kerajaan.

\section{SOROTAN KAJIAN}

Perkembangan barangan berjenama persendirian sangat memberangsangkan bagi kategori harga dan kepelbagaian barangan, tetapi masih tidak dapat menandingi kualiti barangan berjenama nasional (Batra \& Sinha, 2000). Pandangan tersebut disokong oleh Yelkur (2000) yang menegaskan bahawa apabila menyebut mengenai barangan berjenama persendirian ini, pengguna telah memikirkan harga yang rendah, dan oleh sebab itu kualiti barangan tidak seperti yang diharapkan. Sebaliknya, laporan oleh The Nielsen Company (2014) menunjukkan peningkatan di negara-negara Asia Pasifik walaupun peningkatannya tidak sehebat di negara-negara Eropah di mana pengguna telah lama terdedah dengan barangan berjenama persendirian ini. Menurut laporan lagi, hanya 58 peratus pengguna di Asia Pasifik menyatakan bahawa barangan berjenama persendirian adalah setanding barangan nasional, manakala di Utara Amerika adalah sebanyak 75 peratus yakin tentang persamaan barangan berjenama persendirian dan barangan berjenama nasional. Hal ini menunjukkan bahawa peruncit telah memperbaiki barangan berjenama persendirian ini daripada segi kualiti yang menjadi faktor utama pembelian selain daripada harga yang ditawarkan. Masa mengubah pandangan dan kepercayaan pengguna terhadap kualiti barangan berjenama persendirian ini. Pembelian pengguna terhadap barangan isi rumah telah mula berubah dengan membeli barangan berjenama persendirian setelah jenama ini meningkatkan kualiti barangan yang mereka keluarkan (Chien et al., 2014; Koshy, 2008; Saeed \& Grunert, 2014). Pengguna percaya bahawa walaupun barangan berjenama persendirian ini murah tetapi kualiti barangannya setanding barangan berjenama nasional (Baltas \& Argouslidis, 2007; Hassan \& Rahman, 2013).

Barangan berjenama persendirian merupakan satu daripada alternatif kepada pengguna dalam pembelian barangan isi rumah. Pengeluar dan peruncit mengeluarkan jenama mereka sendiri untuk membantu pengguna membuat pilihan dan membeli barangan yang sama dengan harga yang lebih murah berbanding barangan berjenama nasional (Rezwana Manjur, 2014). Menurut Batra \& Sinha, (2000) dan Bilal \& Ali, (2013) jenama persendirian memberikan inisiatif yang baik kepada peruncit termasuk memberikan pulangan margin yang tinggi, membina kesetiaan pelanggan terhadap kedai serta dapat mempelbagaikan barangan.

Kajian oleh pengkaji-pengkaji sebelum ini adalah berbeza mengenai barangan berjenama persendirian ini. Sebagai contoh Calvo Porral dan Lang (2015) melihat daripada perspektif pengeluar, sementara Kremer dan Viot (2012) pula mengkaji daripada perspektif peruncit. Sementara itu, Mokhlis dan Salleh (2009) dan Thanasuta (2015) mengkaji daripada perspektif gelagat pengguna dalam pembuatan keputusan pengguna dalam pembelian barangan berjenama persendirian. Beberapa penyelidikan dijalankan telah membuktikan gelagat pengguna mempengaruhi pembelian sesuatu barangan (Chaniotakis et al., 2010; Jaafar, Lalp, \& Mohamed@Naba, 2013; Morschett, Swoboda, \& Foscht, 2005). Pengguna telah mengubah corak pembelian barangan mereka apabila negara mengalami masalah ekonomi. Sebanyak 66 peratus pengguna di Asia Pasifik dan 81 peratus pengguna di Utara Amerika menyatakan mereka membeli barangan berjenama persendirian adalah disebabkan oleh penjimatan wang (The Nielsen Company, 2014). Kaufman, MacDonald, Lutz, \& Smallwood, (1997) dam Sinha \& Batra, 1(999) mengakui kepentingan barangan berjenama persendirian ini di dalam sektor peruncitan dan jenama ini semakin dikenali dalam kalangan pengguna disebabkan harga yang ditawarkan.

Walau bagaimanapun pengguna yang setia terhadap sesuatu jenama nasional mempunyai tanggapan bahawa barangan berjenama persendirian ini tidak berkualiti dan tidak setanding barangan berjenama nasional (Chang, Eckman, \& Yan, 2011; Sethuraman \& Cole, 2014). Kesetiaan pengguna terhadap barangan nasional dan barangan sedia maklum sukar untuk membuat perubahan. Dapatan daripada kajian (Chaniotakis et al., 2010; Jaafar et al., 2013) mendapati pengguna akan bertukar kepada jenama yang menjimatkan apabila ekonomi kurang stabil dan akan kembali semula kepada jenama yang lama setelah ekonomi pulih. Selain daripada hubungan harga dan kualiti barangan berjenama persendirian yang selalu menjadi perhatian penyelidik, terdapat juga isu-isu menarik tetapi kurang diberikan 
penumpuan. Fernie et al., (2010) memperlihatkan wujudnya hubungan lokasi dengan pendapatan, berdasarkan bukti yang diperoleh bahawa kedai yang berada di pendalaman menawarkan harga yang tinggi berbanding kedai yang berada di bandar kerana peruncit memberikan alasan pengangkutan dan sebagai pengguna, mereka tiada pilihan untuk membeli. Sementara itu, pengkaji-pengkaji seperti Hoddinott \& Haddad, (1995), Kaufman et al., (1997), Parker, Souleles, Johnson, \& McClelland, (2013) telah membuktikan bahawa pengguna yang tinggal di luar bandar mempunyai pendapatan yang rendah. Tambahan pula, kajian KR1M oleh Mohd Saifoul et al. (2014) juga memberikan input berkenaan keadaan dan lokasi kedai yang menjadi kekangan kepada pengguna untuk membeli di kedai ini.

Pemilihan untuk membeli barangan berjenama persendirian ini mengikut keadaan dan situasi pengguna antaranya adalah disebabkan keadaan kos sara hidup yang semakin meningkat selain daripada barangan berjenama persendirian ini makin menampakkan pembaharuan dan peningkatan (Burt \& Davies, 2010; Kaufman et al., 1997; Parker et al., 2013). Kajian tentang kos sara hidup kebiasaannya adalah di dalam bidang ekonomi, tetapi agak terhad yang mengaitkan kos sara hidup dengan pemasaran. Oleh yang demikian, Griffith et al. (2009) mengkaji mengenai kos sara hidup yang meningkat di Amerika Syarikat pada tahun 2007 dan 2008 dan bagaimana keadaan ini mempengaruhi golongan berpendapatan rendah. Imej kedai bagi sesuatu barangan berjenama persendirian ialah muka depan yang menunjukkan keadaan, barangan dan kualiti barangan tersebut. Pengguna akan lebih tertarik ke kedai barangan berjenama persendirian yang mempamerkan kemeriahan papan tanda, menggunakan warna yang menarik untuk logo dan terletak di lokasi yang strategik (Visser, Preez, \& Noordwyk, 2006). Kajian Vahie dan Paswan (2006) telah melihat beberapa perspektif iaitu kepelbagaian barangan, kualiti barangan, harga, nilai kepada wang dan keadaan persekitaran dan dapatan kajian tersebut mendapati selain daripada harga dan kualiti barangan, keadaan persekitaran adalah salah satu daripada penyebab dan keinginan pengguna untuk membuat pembelian di kedai barangan berjenama persendirian.

Kajian mengenai KR1M masih kurang mendapat perhatian penyelidik. Penyelidik sedia ada yang mengkaji mengenai KR1M lebih memfokuskan tentang persepsi dan faktor-faktor yang mempengaruhi pembelian pengguna di KR1M (Mahavera Sheridan, 2015; Alif, 2016; Mohd Saifoul et al., 2014). Dapatan kajian Alif (2016) merungkaikan bahawa harga, kualiti, nilai, imej dan situasi ekonomi signifikan bahawa faktor-faktor ini mempengaruhi pembelian manakala tiada signifikan antara risiko dengan pembelian. Penyelidik lebih tertarik untuk mengkaji mengenai pembelian barangan berjenama persendirian iaitu KR1M membantu pengguna dalam pengurusan kos sara hidup. Bagi menjelaskan hubung kait antara KR1M dan pengurusan kos sara hidup, Teori Proses S-O-R digunakan.

Model Stimulus- Organism- Response merupakan teori psikologi ekonomi yang telah ditambah baik oleh Mehrabian (1974) supaya bersesuaian dengan keadaan semasa. Sebelumnya, hanya Model Stimulus Response diperkenalkan oleh Woodwarth pada tahun 1954 untuk melihat reaksi dan juga tindak balas pengguna terhadap faktor dalaman dan luaran sesuatu keadaan. Stimuli merujuk kepada keadaan persekitaran (Chang et al., 2011) ataupun keadaan dalaman dan juga luaran sesuatu persekitaran (Vieira, 2013). Organisma pula merujuk kepada psikologi, aktiviti pemikiran, tanggapan serta emosi pengguna (Chang et al., 2011; Lin Thang \& Tan, 2003; Sherman, Mathur, \& Smith, n.d.), manakala respons atau tindak balas ialah hasil terakhir yang mempengaruhi pembelian, mempengaruhi pembelian juga merupakan reaksi terakhir pengguna (Lin Thang \& Tan, 2003; Sherman et al., 1997). Melalui pendekatan teori $S-O-R$ ini, stimuli pemasaran atau sosiodemografi dapat diperhatikan secara langsung yang secara umumnya memberikan kesan kepada organisma iaitu pengguna seterusnya mendapat tindak balas (Richardson, Jain, \& Dick, 1996; Sherman et al., 1997).

Lin Thang \& Tan, (2003) menyimpulkan bahawa terdapat lapan dimensi yang memberikan penerangan tentang imej sesebuah kedai. Dimensi ini diadaptasi daripada pengkaji-pengkaji sebelum dan telah menjadi rujukan utama kepada pengkaji. Jadual 1 memperlihatkan tentang lapan dimensi tersebut. Hal ini menjelaskan bahawa imej kedai adalah sangat kompleks secara semula jadi, hal ini mungkin penyebab terdapat banyak definisi mengenai imej kedai yang telah diguna pakai oleh beberapa penyelidik nampak perbezaan. Oleh itu bagi tujuan kajian ini, pengkaji akan menggunakan dimensidimensi imej kedai oleh Lin Thang \& Tan (2003) sebagai rujukan utama dalam menjalankan kajian mengenai pengaruh barangan berjenama persendirian (KR1M) dalam pengurusan kos sara hidup. Hal ini adalah bersesuaian serta bertepatan dengan tujuan kajian. 
Jadual 1: Dimensi Imej Kedai

\begin{tabular}{|l|l|}
\hline Dimensi Imej Kedai & Ciri-ciri \\
\hline Barangan & Kepelbagaian barangan \\
& Nilai untuk wang \\
& Kesediaan barangan \\
\hline Persekitaran & Dekorasi \\
& Susun atur \\
& Kesenangan untuk bergerak \\
& Pameran barangan \\
\hline Perkhidmatan kedai & Nasihat untuk pembelian \\
& Pembungkusan hadiah \\
& Kemudahan pembayaran \\
\hline Kebolehcapaian & Tempat letak kenderaan \\
& Tempoh perjalanan \\
\hline Reputasi & Sejarah \\
& Nilai untuk wang \\
& Kebolehpercayaan \\
\hline Promosi & Pengiklanan \\
& Promosi \\
\hline Fasiliti & Medan selera \\
\hline Perkhidmatan selepas pembelian & Tandas \\
\hline & Penghantaran \\
& Waranti \\
& Polisi pemulangan semula \\
\hline
\end{tabular}

\section{METODOLOGI}

Kajian kuantitatif merupakan pendekatan yang akan digunakan dalam kajian ini. Menurut Bilal \& Ali, (2013), kajian kuantitatif dapat menghasilkan keputusan yang mudah difahami dan secara statistik tepat serta boleh dipercayai disebabkan data yang diperoleh telah dikodkan dalam bentuk numerical bagi memudahkan analisis statistik dilakukan. Kajian kuantitatif menggunakan pengukuran objektif dan analisis kuantitatif yang membolehkan pengkaji untuk menjelaskan penyebab kepada sesuatu perubahan sosial (Firestone 1987).

Kajian ini merupakan reka bentuk kajian deskriptif. Reka bentuk kajian ini membolehkan penggunaan saiz sampel yang besar serta dapat menghasilkan keputusan yang lebih tepat. Menurut Morgan, Gliner dan Harmon (1999), keutamaan penggunaan kajian deskriptif adalah untuk mengenal pasti perhubungan luas yang wujud di antara pemboleh ubah. Ringkasnya, kajian deskriptif adalah untuk menjelaskan sesuatu populasi yang mempunyai kaitan dengan pemboleh ubah kajian. Data yang diperoleh daripada kajian deskriptif akan digunakan untuk menjelaskan ciri-ciri sesuatu kumpulan, menentukan bilangan individu yang mempunyai kelakuan yang tertentu, membuat ramalan yang spesifik serta mengenal pasti perhubungan di antara pemboleh ubah (Morgan et al. 1999; Brown \& Suter 2012).

Jumlah atau bilangan saiz sampel yang betul meningkatkan lagi tahap kesahihan dan kredibiliti sesebuah kajian. Tambahan lagi menurut Malhotra dan Peterson (2006), keputusan yang lebih tepat akan dapat dihasilkan melalui bilangan saiz sampel yang lebih besar. Terdapat beberapa faktor yang menyumbang kepada pemilihan jumlah saiz sampel yang diperlukan dalam sesebuah kajian. Antaranya termasuklah objektif kajian, saiz populasi, kekangan sumber tenaga, kos dan masa serta teknik atau bentuk kajian yang diguna pakai (Sekaran \& Bougie, 2015). Untuk kajian ini, pengkaji menyasarkan saiz sampel berjumlah 300 berdasarkan kepada jadual (Krejcie \& Morgan 1970) yang menganggarkannya sebagai jumlah yang berpatutan bagi mewakili sesebuah populasi. Oleh yang demikian, sejumlah 330 responden merupakan bilangan yang bersesuaian dengan pemboleh ubah yang dimuatkan dalam kajian ini.

Pemilihan teknik pensampelan mudah yang digunakan untuk kajian ini dapat mengelakkan masalah dari segi masa dan juga kos. Selain itu juga, kajian ini menggunakan kaedah tinjauan memintas pasar raya (mall intercept survey method) untuk pengumpulan maklumat, yang akan dilakukan dengan memberikan kaji selidik apabila mereka mengunjungi KR1M dan apabila mereka bersedia untuk melibatkan diri serta memberikan maklum balas dalam kajian ini. 


\section{HASIL DAPATAN}

Bahagian ini akan menerangkan hasil dapatan ujian analisis regresi berganda stepwise yang digunakan bagi tujuan untuk menjelaskan objektif kajian yang telah digariskan. Hasil dapatan kajian tentang perhubungan yang wujud di antara pemboleh ubah peramal dengan pengurusan kos sara hidup dapat dijelaskan melalui keputusan hipotesis yang telah dibangunkan bagi setiap objektif kajian.

\section{Mengenal Pasti Dimensi Imej Kedai KR1M dalam Mempengaruhi Pengurusan Kos Sara Hidup}

Hasil dapatan ujian analisis regresi berganda stepwise juga menunjukkan bahawa terdapat empat pemboleh ubah peramal (barangan, fasiliti, kebolehcapaian dan promosi) yang signifikan dalam mempengaruhi pengurusan kos sara hidup (rujuk Jadual 2).

Jadual 2: Keputusan Pekali Regrasi Berganda Stepwise

\begin{tabular}{|c|c|c|c|c|c|}
\hline \multirow{2}{*}{ Pemboleh Ubah Peramal } & \multicolumn{2}{|c|}{$\begin{array}{c}\text { Pekali Tidak } \\
\text { Terpiawai } \\
\end{array}$} & \multirow{2}{*}{$\begin{array}{c}\begin{array}{c}\text { Pekali } \\
\text { Terpiawai }\end{array} \\
\text { Beta }\end{array}$} & \multirow{2}{*}{$\mathbf{T}$} & \multirow{2}{*}{ Sig. } \\
\hline & B & $\begin{array}{c}\text { Std. } \\
\text { Error }\end{array}$ & & & \\
\hline Konstan & 0.310 & 0.153 & & 2.019 & 0.044 \\
\hline Barangan & 0.560 & 0.041 & 0.574 & 13.7503. & 0.000 \\
\hline Fasiliti & 0.144 & 0.042 & 0.145 & 427 & 0.001 \\
\hline Kebolehcapaian & 0.113 & 0.030 & 0.141 & 3.752 & 0.000 \\
\hline Promosi & 0.111 & 0.030 & 0.132 & 3.727 & 0.000 \\
\hline
\end{tabular}

a. Pemboleh Ubah Bersandar: Pengurusan Kos Sara Hidup

Lapan hipotesis telah diuji untuk merungkai objektif ini. Hasil dapatan kajian menunjukkan bahawa pemboleh ubah imej kedai iaitu barangan $(B=0.560, p<0.05)$, fasiliti $(B=0.144, p<0.05)$, kebolehcapaian $(\mathrm{B}=0.113, \mathrm{p}<0.05)$ dan promosi $(\mathrm{B}=0.111, \mathrm{p}<0.05)$ mempunyai hubungan langsung yang signifikan terhadap pengurusan kos sara hidup ( $\mathrm{R} 2=0.725, \mathrm{~F}=214.541, \mathrm{p}<0.05)$. Sebagai kesimpulannya, berikut merupakan ringkasan kepada hasil dapatan kajian secara keseluruhan (Jadual 3) yang telah diperoleh melalui penggunaan teknik analisis regresi berganda atau multiple regression analysis:

Jadual 3: Ringkasan hasil dapatan

\begin{tabular}{llc}
\hline & \multicolumn{1}{c}{ Hipotesis Kajian } & Hasil Dapatan Kajian \\
\hline H1a & Barangan KR1M mempengaruhi pengurusan kos sara hidup & Disokong \\
H1b & Perkhidmatan KR1M mempengaruhi pengurusan kos sara hidup & Tidak disokong \\
H1c & $\begin{array}{l}\text { Perkhidmatan selepas pembelian di KR1M mempengaruhi } \\
\text { pengurusan kos sara hidup }\end{array}$ & Tidak disokong \\
H1d & Reputasi KR1M mempengaruhi pengurusan kos sara hidup & Tidak disokong \\
H1e & Persekitaran KR1M mempengaruhi pengurusan kos sara hidup & Tidak disokong \\
H1f & Kebolehcapaian KR1M mempengaruhi pengurusan kos sara hidup & Disokong \\
H1g & Fasiliti KR1M mempengaruhi pengurusan kos sara hidup & Disokong \\
H1h & $\begin{array}{l}\text { Promosi Barangan KR1M mempengaruhi pengurusan kos sara } \\
\text { hidup }\end{array}$ & Disokong \\
\hline
\end{tabular}

\section{KESIMPULAN DAN RUMUSAN}

Berdasarkan kepada hasil dapatan kajian menunjukkan bahawa terdapat hubungan yang positif dan signifikan di antara faktor-faktor imej kedai terhadap pembelian barangan berjenama persendirian di KR1M. Walau bagaimanapun, terdapat beberapa faktor di dalam dimensi imej kedai yang negatif dan tidak signifikan. Pemilihan model S-O-R sebagai kerangka asas kajian juga adalah sangat relevan dengan kajian-kajian yang berkaitan dengan tingkah laku pengguna terhadap sesuatu barangan. Hal ini menunjukkan bahawa faktor-faktor yang dikenal pasti dalam kajian ini seperti barangan, persekitaran, 
perkhidmatan kedai, kebolehcapaian, reputasi, promosi, fasiliti dan perkhidmatan selepas pembelian adalah penting dan konsisten dalam mempengaruhi pembelian barangan berjenama persendirian di KR1M. Secara tidak langsung, dapatan kajian ini turut menyokong dapatan kajian terdahulu oleh (Mahavera Sheridan, 2015) yang menyatakan bahawa imej kedai itu adalah penting dalam pembelian barangan di sesuatu kedai.

Hasil dapatan kajian mendapati bahawa faktor barangan menunjukkan terdapat hubungan yang sangat positif dan signifikan terhadap pembelian barangan berjenama 1 Malaysia. Hal ini disebabkan oleh harga dan kualiti barangan yang ditawarkan adalah sangat berpatutan dengan keperluan dan kehendak pelanggan. Selain daripada harga dan kualiti, kepelbagaian barangan juga mendapat perhatian pelanggan untuk membuat pembelian di KR1M. Dapatan ini disokong oleh dapatan Kaswengi (2014) yang menyatakan pelanggan mementingkan kepelbagaian barangan di kedai kerana memudahkan pelanggan untuk membuat pilihan selain daripada menyenangkan mereka.Selain itu, kajian mendapati bahawa faktor persekitaran menunjukkan tidak terdapat hubungan yang signifikan dalam pembelian barangan berjenama 1 Malaysia. Ini memperlihatkan bahawa faktor persekitaran adalah tidak penting bagi pelanggan. Ini kemungkinan disebabkan oleh persekitaran dan suasana KR1M ini adalah sama seperti kedai runcit yang lain.

\section{Implikasi Kajian}

Setelah kajian dijalankan, pengkaji mendapati bahawa ternyata dan terbukti bahawa imej kedai adalah stimuli penting dalam mendapat perhatian pelanggan bagi membuat pembelian di kedai. Respons pelanggan terhadap stimuli imej kedai memberikan impak yang positif pembelian barangan berjenama persendirian. Teori S-O-R (Stimuli - Organism - Respon) biasanya digunakan dalam bidang ekonomi untuk melihat perhubungan. Walau bagaimanapun pengkaji menggunakannya dalam pemasaran untuk melihat aspek gelagat pengguna. Tetapi ianya terbukti boleh digunakan untuk melihat perhubungan antara imej kedai dan sosio demografi pelanggan-pelanggan KR1M dengan pembelian mereka dalam menguruskan kos sara hidup. Terdapat juga beberapa pengkaji pemasaran yang menggunakan teori SO-R ini termasuk (Sherman et al.,1997) untuk melihat persekitaran kedai mempengaruhi gelagat pengguna dalam pembelian di kedai.

Kajian membuktikan imej kedai adalah sangat penting dalam mempengaruhi pembelian isi rumah di KR1M. Imej kedai yang baik ini turut menyumbang kepada peningkatan jualan di KR1M. Keadaan ini menguntungkan pemasar kerana isi rumah memilih untuk membeli barangan mereka di sini. Kesannya, keadaan ini menyumbang kepada pertumbuhan dalam bidang peruncitan terutamanya KR1M.

\section{Cadangan Kajian Masa Hadapan}

Pengkaji akan datang boleh meluaskan lagi pemboleh ubah yang sedia ada dalam menentukan pemboleh ubah terbaik dalam kajian akan datang. Pengkaji juga mencadangkan agar kaedah penyelidikan kuantitatif dan kualitatif digabungkan di masa hadapan bagi meningkatkan keyakinan terhadap penemuan kajian dan kualiti tafsiran data (Mangleburg, 1990). Walaubagaimanapun, kejayaan KR1M ini bergantung kepada polisi yang dilaksanakan oleh kerajaan Malaysia. Perubahan dalam politik di Malaysia memberi kesan yang negatif ke atas KR1M di masa hadapan.

\section{RUJUKAN}

Akpoyomare, O. B., Patrick, L. P. K. \& Ganiyu, R. A. 2012. The Influence of Product Attributes on Consumer Purchase Decision in the Nigerian Food and Beverages Industry: A Study of Lagos Metropolis. American Journal of Business and Management, 1(4), 196-201.

Baltas, G. \& Argouslidis, P. C. (2007). Consumer characteristics and demand for store brands. International Journal of Retail \& Distribution Management, 35(5), 328-341. doi:10.1108/09590550710743708

Bilal, M. \& Ali, T. (2013). Factors influencing consumer's purchase intentions towards private brands. Journal of Independent Studies and Research-Management, 11(2), 17-28.

Boutsouki, C., Zotos, Y. \& Masouti, Z. 2008. Consumer Behaviour towards Own Label: monitoring the Greek experience. Agricultural Economics Review, 9(1), 81-92. 
Calvo Porral, C., \& Lang, M. F. (2015). Private labels: rhe role of manufacturer identification, brand loyalty and image on purchase intention. British Food Journal, 117(2), 506-522.

Carpenter, J. M. \& Moore, M. (2006). Consumer demographics, store attributes, and retail format choice in the US grocery market. International Journal of Retail \& Distribution Management, 34(6), 434-452. doi:10.1108/09590550610667038

Chang, H.-J., Eckman, M. \& Yan, R.-N. (2011). Application of the stimulus-organism-response model to the retail environment: the role of hedonic motivation in impulse buying behavior. The International Review of Retail, Distribution and Consumer Research, 21(3), 233-249. doi:10.1080/09593969.2011.578798

Chien, S., Yu, C., Wang, Y. \& Kuo, P.-L. (2014). Improving the perceived quality of private brands using cobranding: the role of brand equity and store image. International Journal of Management and Sustainability, 3(9), 540-551.

Chintagunta, P. K., Bonfrer, A., \& Song, I. (2002). Investigating the effects of store-brand introduction on retailer demand and pricing behavior. Management Science, 48(10), 1242-1267.

Gjonca, E. \& Calderwood, L. (2004). Socio-demographic characteristics. Health, Wealth And Lifestyles Of The Older Population In England: The 2002 English Longitudinal Study Of Ageing, 15-32. Doi:10.1016/0020-7489(70)90025-8

Griffith, R., Leibtag, E., Leicester, A., \& Nevo, A. (2009). Consumer shopping behavior: how much do consumers save? Journal of Economic Perspectives, 23(2), 99-120. doi:10.1257/jep.23.2.99

Hafifi, M. A. (2016). Consumers' perception and purchase intention toward private label products of KR1M (January).

Hassan, H. \& Rahman, M. S. (2013). The Value of National Brand and Local Brand. Journal of Basic and Applied Scientific Research, 3(3), 784-786.

Huang, E. (2012). Online experiences and virtual goods purchase intention. Internet Research, 22(3), 252-274.

Jaafar, S. N., Lalp, P. E., \& Naba, M. M. (2012). Consumers' perceptions, attitudes and purchase intention towards private label food products in Malaysia. Asian Journal of Business and Management Sciences, 2(8), 7390.

Kaswengi, J. (2014). Store image dimensions and brand equity: the moderating role of demographic characteristics. In Proceedings of the 13th edition of the International Marketing Trends Conference.

Kaufman, P. R., MacDonald, J. M., Lutz, S. M. \& Smallwood, D. M. (1997). Do the poor pay more for food? Item selection and price differences affect low-income household food costs. Journal of interferon cytokine research the official journal of the International Society for Interferon and Cytokine Research, 31(1), 941. doi:10.4155/fmc. 12.40

Kim, J., Lennon, S. J., Chang, H. H., Chen, S. W., Goyal, A., Maity, M., Thamizhvanan, A. et al. (2013). Journal of research in interactive marketing effects of reputation and website quality on online consumers' emotion, perceived risk and purchase intention: Based on the stimulus-organism-response model. Journal of Research in Interactive Marketing Iss Journal of Indian Business Research Iss, 7(1), 33-56. Retrieved from http://dx.doi.org/10.1108/17505931311316734

Koul, S. \& Mishra, H. G. (2014). Customer perceptions for store attributes: A study of traditional retail stores in india. Journal of Business \& Economics, 5(1), 79-103. doi:10.4172/2151-6219.1000127

Krejcie, R. V \& Morgan, D. W. (1970). Determining sample size for research activities. Educational and Psychological Measurement, 30, 607-610. doi:10.1177/001316447003000308

Kremer, F. \& Viot, C. (2012). How store brands build retailer brand image. International Journal of Retail \& Distribution Management, 40(7), 528-543. doi:10.1108/09590551211239846

Lamey, L., Deleersnyder, B., Dekimpe, M. G. \& Steenkamp, J.-B. E. (2007). How business cycles contribute to private-label success: Evidence from the united states and europe. Journal of Marketing, 71(1), 1-15. doi:10.1509/jmkg.71.1.1

Lin Thang, D. C. \& Tan, B. L. B. (2003). Linking consumer perception to preference of retail stores: An empirical assessment of the multi-attributes of store image. Journal of Retailing and Consumer Services. doi:10.1016/S0969-6989(02)00006-1

Mahavera Sheridan. (2015). Benarkah KRIM berbaloi bagi golongan kelas pekerja. The Malaysian Insider.

Mohd Saifoul, Z. N., Jalal, A. \& Amir Hussin, B. (2014). Persepsi Pengguna Terhadap Barangan Keperluan Berjenama 1. Prosiding PERKEM 9, 9, 689-703.

Mokhlis, S. \& Salleh, H. (2009). Consumer Decision Making Styles In Malaysia: An Exploratory Study Of Gender Differences. European Journal of Social Sciences, 10(4), 574-584.

Morschett, D., Swoboda, B. \& Foscht, T. (2005). Perception of store attributes and overall attitude towards grocery retailers: The role of shopping motives. The International Review of Retail, Distribution and Consumer Research, 15(4), 423-447. doi:10.1080/09593960500197552

Parker, J. A., Souleles, N. S., Johnson, D. S. \& McClelland, R. (2013). Consumer spending and the economic stimulus payments of 2008. American Economic Review, 103(6), 2530-2553. doi:10.1257/aer.103.6.2530 
Porter, S. S. \& Claycomb, C. (1997). The influence of brand recognition on retail store image. Journal of Product \& Brand Management, 6(6), 373-387. doi:10.1108/10610429710190414

Private Label Manufacturers Association. (2010). "Store Brands 2010: Post-Recession Strategies for Private Label." http://www.sju.edu/resources/libraries/campbell/researchguides/securefiles/PLMAroundtable_report.pd f. [5 Julai 2017]

Rezwana Manjur. (2014). Retailers' private labels perceived more favourably. https://www.marketinginteractive.com/consumers-positive-toward-retailers-private-labels/ [23 July 2018].

Richardson, P., Jain, A. K. \& Dick, A. (1996). The influence of store aesthetics on evaluation of private label brands. Journal of Product \& Brand Management, 5(1), 19-28. doi:10.1108/10610429610113384

Saeed, F. \& G. Grunert, K. (2014). Expected and experienced quality as predictors of intention to purchase four new processed beef products. British Food Journal, 116(3), 451-471. doi:10.1108/BFJ-10-2011-0262

Sekaran, U. \& Bougie, R. (2015). Research Methods for Business: A Skill-Building Approach.Sixth Edit. New Delhi.

Sethuraman, R., \& Cole, C. (1999). Factors influencing the price premiums that consumers pay for national brands over store brands. Journal of Product \& Brand Management, 8(4), 340-351.

Shakil Hameed \& Noor Mohamad. (2012). KRlM cetus fenomena. Harian Metro, (11 October), p. 20.

Sherman, E., Mathur, A. \& Smith, R. B. R. (1997). Store Environment and Consumer Purchase Behavior: Mediating Role of Consumer Emotions. Psychology and Marketing, 14(4), 361-378.

Sinha, I. \& Batra, R. (1999). The effect of consumer price consciousness on private label purchase. International Journal of Research in Marketing, 16(3), 237-251. doi:10.1016/S0167-8116(99)00013-0

Thanasuta, K. 2015. Thai consumers' purchase decisions and private label brands. International Journal of Emerging Markets, 10(1), 102-121. doi:10.1108/IJOEM-02-2011-0016

Tien, N. T. T. (2014). A research on factors affecting consumer buying behavior-A case of The Faceshop cosmetic brand in Ho Chi Minh city (Doctoral dissertation, International University HCMC, Vietnam).

Vahie, A. \& Paswan, A. (2006). Private label brand image: its relationship with store image and national brand. International Journal of Retail \& Distribution Management, 34(1), 67-84. doi:10.1108/09590550610642828

Wang, C. \& Ha, S. (2011). Store attributes influencing relationship marketing: a study of department stores. Journal of Fashion Marketing and Management, 15, 326-344. doi:10.1108/13612021111151923

Yelkur, R. (2000). Consumer perceptions of generic products: a Mexican study. The Journal of Product and Brand Management, 9(7), 446-456. doi:10.1108/10610420010351385

Young, S. 2005. Competing against private label: New insights from packaging research 20-29. 